\section{Inkluderende maskulinitet}

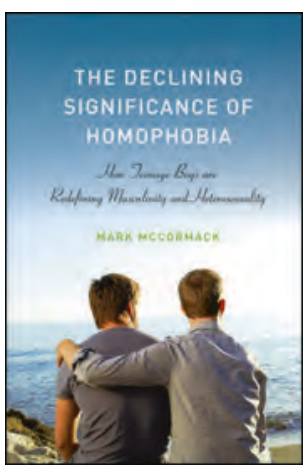

Mark McCormack

The declining significance of homophobia

How teenage boys are redefining masculinity and heterosexuality. 166 s, ill. Oxford: Oxford

University Press, 2012. Pris GBP 33

ISBN 978-0-19-977824-9

Boken utgis av Oxford University Press i en serie forlaget kaller Sexuality, Identity, and Society Series, hvis formål er å fremme kreativ vitenskapelig kunnskap innenfor forskning på kjønn og seksualitet.

Forfatteren redegjør for en etnografisk studie som han har utført av ungdommers maskulinitet og holdning til homofile i dag. Boken har nok størst interesse for personer som forsker på kjønn eller homofiles situasjon, men den er relevant også for barne- og ungdomspsykiatere, lærere og andre som jobber med ungdom. Relevansen for den gjengse lege er lav, men for det samfunnsengasjerte menneske vil den være et interessant innspill om hvordan samfunnet endrer seg, og hvordan vi skal forstå oss selv som menn, kvinner og mennesker.

I 2009 gjennomførte McCormack den ett år lange etnografiske studien av gutter i alderen 16-18 år på tre ulike skoler i England. Forfatteren var sammen med og observerte elevene i skoletiden, og intervjuet noen av studentene. Han drøfter sin egen rolle grundig, og forskningsmessig ser dette ut til å være et solid arbeid. I tillegg til å beskrive sine funn redegjør han for tidligere forskning og ulike teorier innenfor maskulinitetsstudier. Av de tre hoveddelene omhandler første del etnografisk forskning generelt og hvordan studien ble utført, andre del omtaler forskningsfunn og teorier innenfor sosiologiske studier av maskulinitet, og i tredje del beskriver og fortolker han funnene i studien.

To hovedretninger innen teorier om maskulinitet drøftes. Innenfor hegemonisk maskulinitet er ulike måter å være mann på hierarkisk rangert, og de best ansette mennene dominerer og marginaliserer de lavere rangerte mennene. Homofobi brukes til å korrigere atferd som man anser som umandig, og er derfor viktig for både heterofile og homofile gutter og menn. Innenfor inkluderende maskulinitet eksisterer ulike maskulinitetstyper side om side og har lik verdi. Studien viser at hegemonisk maskulinitet opererer i miljøer der man er negativ til homofili, mens inkluderende maskulinitet gjelder der homofili aksepteres.

Det oppsiktsvekkende ved studien er at den dokumenterte at homofobi (også den homofobiske språkbruken) var fraværende, og homofili var fullt akseptert. Popularitet og sosial kapital blant guttene baserte seg ikke på dominerende maskulinitetstyper, men bygde på andre verdier: karisma (energifull, underholdende, finne på gøyale ting, være litt «gæren»), autentisitet (samsvar mellom den man utgir seg for å være, og den man faktisk er), emosjonell støtte (til alle) og sosial kompetanse (man omgås alle typer gutter og ekskluderer ikke de mindre populære). Vold, mobbing og nedsettende kommentarer var ansett som uakseptabelt og avleggs.

Forfatteren mener at homofobi var på topp i 1980- og 90-årene, og at endringen til en inkluderende maskulinitet har funnet sted på 2000-tallet. Forkjempere for homofiles rettigheter, aids som synliggjorde at «hvem som helst» kunne være homofil, økonomiske endringer med $\varnothing \mathrm{kt}$ utdanningsnivå og Internett som «vanliggjør» ulike måter å være mann på og ha sex på, har bidratt til utviklingen, skriver han.
For meg ga boken oppdatert og gledelig kunnskap om situasjonen vedrørende kjønnsroller og homofiles situasjon blant ungdom per i dag. Jeg liker også forfatterens argumentering for at kategorisering basert på seksuell identitet er nyttig, og at han fremhever at man ikke lenger trenger å se på homofile som ofre.

\section{Mari Bjørkman}

Avdeling for allmennmedisin Institutt for helse og samfunn Universitetet i Oslo

\section{Meget nyttig om håndtering av alvorlige hodeskader}

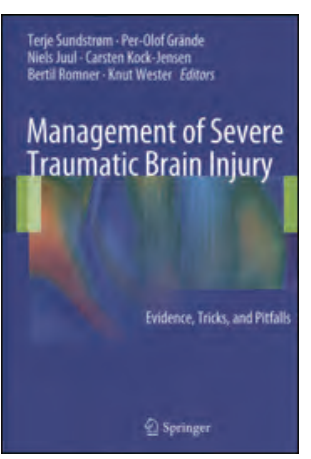

Terje Sundstrøm, Per-Olof Grände,

Niels Juul et al, red.

Management of severe traumatic brain injury

Evidence, tricks, and pitfalls. 417 s, tab, ill. Heidelberg: Springer, 2012. Pris EUR 139 ISBN 978-3-642-28125-9

The Scandinavian Neurotrauma Committee (SNC), med representanter fra Sverige, Danmark, Norge, Finland og Island, har de siste tiårene kommet med vesentlige bidrag til å systematisere og bedre håndteringen av pasienter med nevrotraumer i Skandinavia. Siste bidrag fra SNC er denne meget nyttige boken om alle trinn i behandlingen av alvorlige hodeskader fra skadested til rehabilitering.

Boken er systematisk, velskrevet og lettlest. Innholdsfortegnelsen er god slik at man lett finner frem til det man søker kunnskap om. Forfatterne gir oss videre et godt innblikk i hva som er evidensbasert kunnskap, og hva som er mer erfaringsbasert kunnskap.

Denne boken vil være til stor nytte og glede for alle typer helsepersonell som deltar i håndteringen av pasienter med alvorlige hodeskader. Boken bør være lett tilgjengelig på alle sykehusavdelinger som behandler denne pasientgruppen.

Jeg anbefaler boken.

\section{Eirik Helseth}

Nevrokirurgisk avdeling

Oslo universitetssykehus, Ullevål 